\title{
Histopathology of Diphyllobothrium ditremum plerocercoids in coho salmon Oncorhynchus kisutch
}

\author{
Keith A. Weiland, Theodore R. Meyers* \\ Alaska Department of Fish and Game, Fisheries Rehabilitation, Enhancement and Development Division, PO Box 3-2000 \\ Juneau, Alaska 99802, USA
}

\begin{abstract}
Captive and transplanted juvenile coho salmon Oncorhynchus kisutch Walbaum dying from an epizootic of plerocercoid parasitism by Diphyllobothrium ditremum (Creplin) in 2 Alaskan lakes were examined for gross and histological lesions. Clinical signs in moribund fish included severe ascites, abdominal distension with loss of equilibrium, visceral adhesions, hemorrhaging and discoloration of the liver and abundant plerocercoids within major organs and loose within the visceral cavity. The primary microscopic lesion was edema, congestion and hemorrhaging within hepatic sinusoids accompanied by occasional tracks of damaged hepatic tissue caused by migrating plerocercoids. The lesions suggest that fish mortality was due to liver dysfunction, blood loss and osmotic imbalance.
\end{abstract}

\section{INTRODUCTION}

In Alaska, a recent method of salmonid rearing has been the use of 1-way barriered lakes for the fry-tosmolt development of coho Oncorhynchus kisutch Walbaum and chinook $O$. tshawytscha Walbaum salmon. However, parasitism of transplanted fingerlings by Diphyllobothrium sp. plerocercoids has limited the success of this method in certain lakes. In late June 1983 115300 coho salmon were stocked in Elfendahl Lake on Chichagof Island, Alaska by a private, nonprofit, aquaculture association. Within 2 mo of release, coho salmon mortality began to appear. Necropsy and bacteriological examination of moribund fish did not detect any other causative agent other than myriads of diphyllobothrid plerocercoids within the viscera and peritoneal cavity. Only $7 \%$ of these fish survived to enter seawater the following spring. Generally, expected survival should be 67 to $73 \%$ (NSRAA unpubl. data). In June 1984, the National Marine Fisheries Service transplanted 141500 chinook salmon fingerlings into Osprey Lake on Baranof Island, Alaska. By August, numerous mortalities were evident, signs were similar to those presented by coho salmon from Elfendahl Lake. Necropsy results were also identical, and less than $18 \%$ of these transplanted chinook sal-

- Addressee for reprint requests mon survived to enter seawater by the next spring. A bioassay study (Weiland 1988), reported separately, was designed to reproduce plerocercoid related mortality under experimental conditions in Osprey Lake by placing nonparasitized hatchery-reared coho salmon fingerlings into net pens from June through to November. Fish became parasitized by feeding on parasitized 1st intermediate plankton hosts. Briefly, plerocercoids of $D$. ditremum were observed in $91 \%$ of penned coho salmon within $20 \mathrm{~d}$ of exposure with cumulative mortalities of 46.2 and $22.4 \%$ observed in 2 pens, respectively, Moribund and dead coho salmon both had significantly more worms than apparently normal, but infected fish (Weiland 1988). The clinical signs and necropsy results were identical to those obtained from both coho and chinook salmon dying within the natural epizootics above

Whether or not parasitism by diphyllobothrid polerocercoids results in natural fish mortality has been cause for controversy in the literature. There are reports of mass mortality in salmonids implicating diphyllobothrid plerocercoids (Simms \& Shaw 1931 Duguid \& Sheppard 1944, Hickey \& Harris 1947, Fraser 1960, Hoffman \& Dunbar 1961, Becker 1966, Becker \& Brunson 1967, Hoffman 1967). More specifically, the importance of Diphyllobothrium ditremum in parasite induced host mortality has been questioned (Halvorson 1970, Henricson 1977, 1978) until more recently when 
it has been suggested as a cause of mortality in intermediate host populations of fish (Halvorson \& Anderson 1984, Berube \& Curtis 1986). Available reports regarding pathologic effects have been on population or macroscopic levels (Hickey \& Harris 1947. Fraser 1960, Hoffman \& Dunbar 1961. Bylund 1972), but there are no detailed descriptions of histopathology in salmonids dying from epizootics caused by $D$. ditremum or other diphyllobothrid plerocercoids. The intent of this report is to describe the histopathological changes and probable causes of mortality in coho salmon fingerlings dying from $D$. ditremum plerocercoid parasitism when transplanted and experimentally held captive in a natural water body where diphyllobothrid plerocercoids have been indigenous.

\section{MATERIALS AND METHODS}

Eight coho salmon collected from a population of transplanted fish ( $85 \mathrm{~mm}$ fork length) sustaining a plerocercoid epizootic in Elfendahl Lake on Chicagof Island, Alaska in August 1983 were fixed in 10\% buffered formalin. Six additional coho salmon (60 to $67 \mathrm{~mm}$ fork length) from a captive population showing clinical signs of plerocercoid parasitism were also collected from Osprey Lake on Baranof Island, Alaska in August and October 1985 and fixed in $70 \%$ ethyl alcohol. The gross pathology was described from necropsies on 235 fish. Samples from all major organs and tissues of Elfendahl fish were excised for standard histological processing using 4 to $5 \mu \mathrm{m}$ sections stained in hematoxylin and eosin $(\mathrm{H} \& \mathrm{E})$. The smaller Osprey Lake specimens were processed whole.

Identification of plerocercoids was established by Dr Hilda Lei Ching (Hydra Enterprises Ltd, Vancouver, B. C.) using scanning electron microscopy. Characteristics were in best agreement with those of Anderson et al. (1987) for the species Diphyllobothrium ditremum.

\section{RESULTS}

\section{Gross pathology}

The single external clinical sign of disease was a marked distention of the abdomen resulting from a clear ascites. In acute cases fish struggled to stay upright, and often floated upside down. Internal gross examination showed adhesions, hemorrhaging, and discolorations of visceral tissues, particularly of the liver. The amount of adipose tissue in parasitized fish was reduced. Plerocercoids were primarily observed loose in the body cavity, but also encysted and unencysted within the stomach wall, connective tissues around the pyloric caecae, adipose tissue, and liver The average number of worms causing ascites and fish mortality ranged from 28 to 32 , compared to 11 in subclinically parasitized fish (Weiland 1988).

\section{Histopathology}

Microscopic examination showed hemorrhaging within tissues invaded by plerocercoids. Liver was the primary affected organ with edema and congestion of sinusoids causing disruption of the muralial architecture and frank hermorrhaging (Figs. 1, 2, and 3). Migrating larvae were present and also left 'tracks' of damaged hepatic tissues with little or no fibrosis (Figs. 1 and 4). Host encapsulation of migrating larvae was not pronounced in any of the tissues invaded.

\section{DISCUSSION}

Significant fish mortality from Diphyllobothrium ditremum plerocercoid parasitism in transplanted juvenile coho $(51 \%)$ and chinook (40\%) salmon, and in caged coho fingerlings $(34 \%)$ has been described in a previous manuscript (Weiland 1988). In parasitized fish the organ most affected and primarily responsible for the major clinical sign of ascites was the liver. Plerocercoid migration damaged hepatic veins obstructing venous flow from the liver causing sinusoidal edema, passive congestion, hepatic necrosis and eventual hemorrhaging within the liver. This condition, also causing the liver discoloration visible grossly, increased intravascular pressure resulting in a transudative edema within the coelom presenting as ascites. Death probably resulted from a combination of liver dysfunction, blood loss, and osmotic imbalance. Increasing worm length (up to $17 \mathrm{~mm}$ ) was indicative of older vs new infestations in which plerocercoids were less than $2 \mathrm{~mm}$. Host encapsulation of plerocercoids was uncommon though not likely during the short July to October period when fish were sampled. Consequently, unrestrained parasite migration further contributed to fish hosts being overwhelmed by relatively few plerocercoid numbers. Mortality, in part, may also have been due to the small host size and that these fish represented a naive hatchery population less resistent to the effects of parasitism than larger resident fish species. Indirect mortality from parasitism could also have resulted from predation of compromised host fish unable to equilibrate due to the marked ascites and abdominal distension.

It is clear from this study that small numbers of these plerocercoids can cause severe liver trauma killing significant numbers of fingerling salmonid fishes in experimental and natural circumstances 


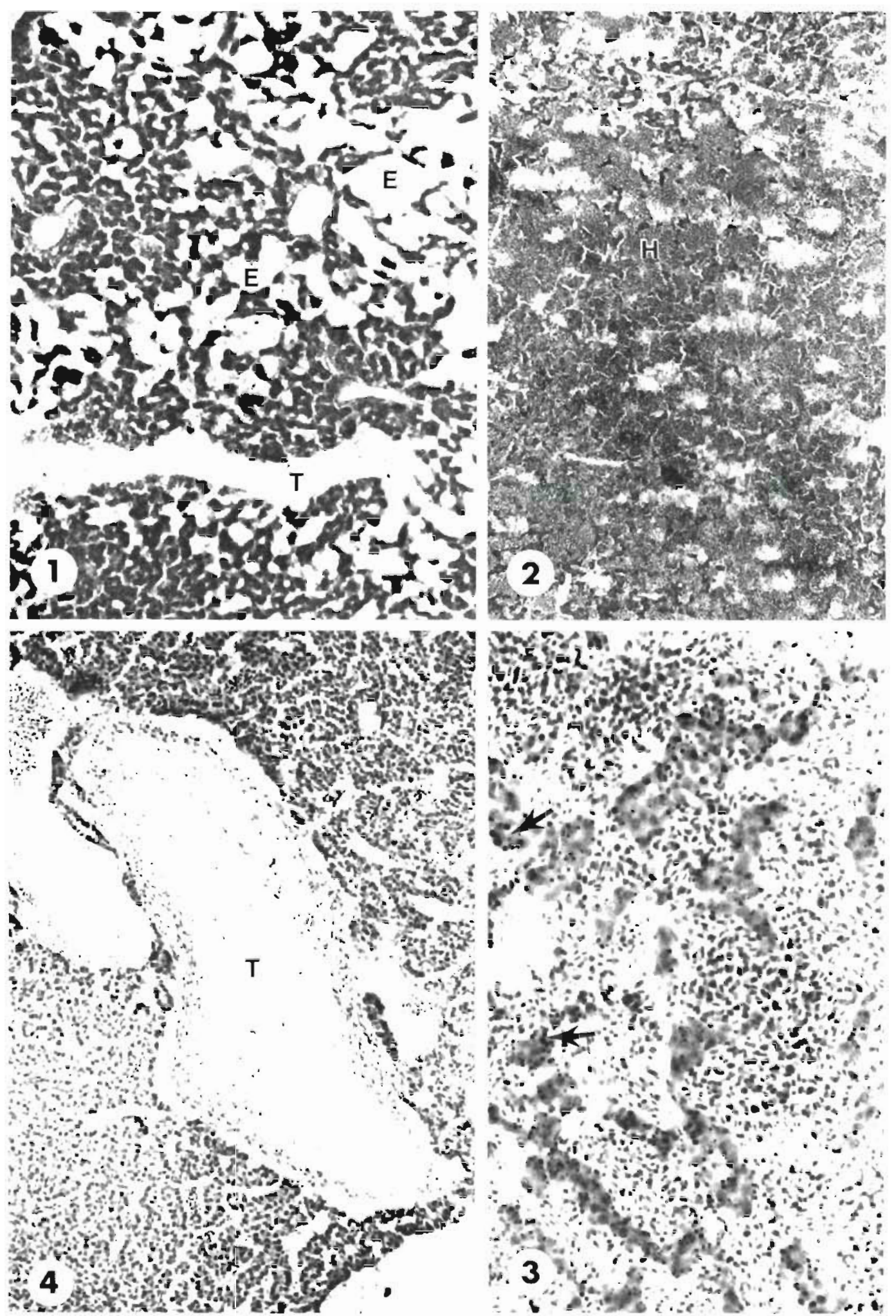

Figs. 1 to 4. Oncorhynchus kisutch. Liver of coho salmon fingerlings infected with Diphyllobothrium ditremum plerocercoids $(H \& E)$. Fig. 1. Hepatocyte edema (E) distorting muralial architecture and a plerocercoid 'track' (T) $(\times 360)$. Fig. 2. Severe congestion and hemorrhage $(H)$ within hepatic sinusoids $(\times 144)$. Fig. 3. Higher magnification of hemorrhagic area in Fig. 2 showing hemosiderin-type granules (arrows) within hepatocytes $(\times 720)$. Fig. 4. Plerocercoid track $(T)$ within normal area of liver filled with fibrin-like material with only slight fibrosis evident around periphery $(\times 360)$ 
Acknowledgements. We thank Sally Short, Alaska Department of Fish and Game. Division of Fisheries Rehabilitation, Enhancement and Development for her help in histological preparation of this material. Financial support for this research was provided by the Northern Southeast Regional Aquaculture Association (NSRAA)

\section{LITERATURE CITED}

Andersen, K., H. L. Ching, Vik, R. (1987). A review of freshwater species of Diphyllobothrium with redescriptions and the distribution of $D$. dendriticum (Nitzsch 1824) and $D$. ditremum (Creplin 1825) from North America. Can. J. Zool. 65: $2216-2228$

Becker, C. D. (1966). Helminth infections in Washington salmonids with considerations for management. Fisheries Research Institute: University of Washington, Seattle. Circular No. 66-15: 40

Becker, C. D., Brunson, W. D. (1967). Diphyllobothrium (Cestoda) infections in salmonids from three Washington lakes. J. Wild. Mggmt 31: 813-824

Berube, M., Curtis, M. A. (1986). Transmission of Diphyllobothrium ditremum to Arctic char (Salvelinus alpinus) in two subarctic Quebec lakes. Can. J. Fish. aquat. Sciences 43: $1626-1634$

Bylund, G. (1972). Pathogenic effects of a diphyllobothriid plerocercoid on its host fishes. Commentat. biol. 58: 1-11

Duguid, J. B., Sheppard, E. M. (1944). A Diphyllobothrium epidemic in trout. J. Path. Bact. 56: 73-80

Fraser, P. G. (1960). The occurrence of Diphyllobothrium in trout with special reference to an outbreak in the west of England. J. Helminth. 34: 59-72
Halvorsen, O. (1970). Studies of the helminth fauna of Norway $\mathrm{XV}$ : On the taxonomy and biology of plerocercoids of Diphyllobothrium Cobbold, 1858 (Cestoda: Pseudophyllidea) from northern-western Europe. Nytt Mag. Zool. 18: $113-174$

Halvorsen, O., Andersen, K. (1984). The ecological interaction between arctic char Salvelinus alpinus (L.) and the plerocercoid stage of Diphyllobothrium ditremum. J. Fish Biol. 25: 305-316

Henricson, J. (1977). The abundance and distribution of Diphyllobothrium dendriticum (Nitzsch) and D. ditremum (Creplin) in the char Salvelinus alpinus (L.) in Sweden. J. Fish. Biol. 13: 51-71

Henricson, J. (1978). The dynamics of infection of Diphyllobothrium dendriticum (Nitzsch) and D. ditremum (Creplin) in char Salvelinus alpinus (L.) in Sweden. J. Fish Biol. 13: $51-71$

Hickey, M. D., Harris, J. R. (1947). Progress of the Diphyllobothrium epizootic at Poulaphouca Reservoir, Co. Vickiluw, Ireland. J. Helminth. 22: 13-28

Hoffman, G. L. (1967). Parasites of North American freshwater fishes. University of California Press, Berkeley, Los Angeles

Hoffman, G. L., Dumbar, C. E. (1961). Mortality of eastern brook trout caused by plerocercoids (Cestoda, pseudophyllidea: Diphyllobothridae) in the heart and visera. J. Parasit. 47: 399-400

Simms, B. T., Shaw, J. N. (1931). Studies on the fish-borne tapeworm Diphyllobothrium cordiceps Leidy. J. Am. Med Assoc. 79: 199-205

Weiland, K. A. (1988). Prestocking assessment of the prevalence and intensity of Diphyllobothrium ditremum (Creplin) plerocercoids in freshwater barriered lakes in Alaska. M. S. Thesis. University of Alaska, Juneau 